OPEN ACCESS

Edited by: Jon Pittman,

University of Manchester, United Kingdom

Reviewed by: Christel Baum,

University of Rostock, Germany

Andrew Peter Dean,

Manchester Metropolitan University,

United Kingdom

*Correspondence:

Charu Lata

charulata@nbri.res.in

charulata14@gmail.com

Specialty section:

This article was submitted to

Plant Traffic and Transport,

a section of the journal

Frontiers in Plant Science

Received: 30 November 2017 Accepted: 22 March 2018

Published: 06 April 2018

Citation:

Tiwari S and Lata C (2018) Heavy Metal Stress, Signaling, and Tolerance

Due to Plant-Associated Microbes: An Overview. Front. Plant Sci. 9:452.

doi: 10.3389/fpls.2018.00452

\section{Heavy Metal Stress, Signaling, and Tolerance Due to Plant-Associated Microbes: An Overview}

\author{
Shalini Tiwari and Charu Lata* \\ CSIR-National Botanical Research Institute, Lucknow, India
}

Several anthropogenic activities including mining, modern agricultural practices, and industrialization have long-term detrimental effect on our environment. All these factors lead to increase in heavy metal concentration in soil, water, and air. Soil contamination with heavy metals cause several environmental problems and imparts toxic effect on plant as well as animals. In response to these adverse conditions, plants evolve complex molecular and physiological mechanisms for better adaptability, tolerance, and survival. Nowadays conventional breeding and transgenic technology are being used for development of metal stress resistant varieties which, however, are time consuming and labor intensive. Interestingly the use of microbes as an alternate technology for improving metal tolerance of plants is gaining momentum recently. The use of these beneficial microorganisms is considered as one of the most promising methods for safe crop-management practices. Interaction of plants with soil microorganisms can play a vital role in acclimatizing plants to metalliferous environments, and can thus be explored to improve microbe-assisted metal tolerance. Plant-associated microbes decrease metal accumulation in plant tissues and also help to reduce metal bioavailability in soil through various mechanisms. Nowadays, a novel phytobacterial strategy, i.e., genetically transformed bacteria has been used to increase remediation of heavy metals and stress tolerance in plants. This review takes into account our current state of knowledge of the harmful effects of heavy metal stress, the signaling responses to metal stress, and the role of plant-associated microbes in metal stress tolerance. The review also highlights the challenges and opportunities in this continued area of research on plant-microbe-metal interaction.

Keywords: bioavailability, heavy metals, microbes, remediation, stress, tolerance

\section{INTRODUCTION}

Heavy metal stress has become a major concern in various terrestrial ecosystems worldwide. Nowadays extensive industrialization imparts detrimental effects on soil as well as on crop productivity by accumulating heavy metals (Shahid et al., 2015). Damage to soil texture, i.e., pH of soil, presence of different elements, and accumulation of heavy metals cause direct and/or indirect reduction of plant growth by adversely affecting various physiological and molecular activities of plants (Panuccio et al., 2009; Hassan et al., 2017). Heavy metals such as $\mathrm{Zn}, \mathrm{Cu}, \mathrm{Mo}, \mathrm{Mn}, \mathrm{Co}$, 
and $\mathrm{Ni}$ are essential for crucial biological processes and developmental pathways (Salla et al., 2011; Shahid et al., 2015). However, these metals along with four other highly toxic heavy metals including, arsenic (As), lead (Pb), cadmium (Cd), mercury $(\mathrm{Hg}), \mathrm{Cr}, \mathrm{Al}$, and $\mathrm{Be}$ can reduce crop productivity to a great extent when their concentration rises beyond supraoptimal values (Xiong et al., 2014; Pierart et al., 2015). These toxic elements cause morphological abnormalities, and metabolic disorders that lead to yield reduction in plants (Amari et al., 2017). These abnormalities also give rise to the production of reactive oxygen species (ROS), e.g., superoxide anion radical $\left(\mathrm{O}^{2-}\right), \mathrm{H}_{2} \mathrm{O}_{2}$, and hydroxyl radical $\left(\mathrm{OH}^{-}\right)$, resulting in disruption of the redox homeostasis of cells (Gill and Tuteja, 2010; Pourrut et al., 2011; Ibrahim et al., 2015; Shahid et al., 2015). This redox status misbalance is known to be a major cause of heavy metal toxicity in plants. Earlier studies reported the negative impact of accumulation of heavy metals in food crops on human health (Nabulo et al., 2011; Uzu et al., 2011; Shahid et al., 2015). To withstand heavy metal stress and metal toxicity, plants have evolved numerous defense mechanisms viz reduced heavy metal uptake, sequestration of metal into vacuoles, binding to phytochelatins/metallothioneins, and activation of various antioxidants (Shahid et al., 2015).

To decipher regulatory networks involved in response to heavy metal tolerance in plants, various omics approaches such as transcriptomics, proteomics, and metabolomics are being routinely used (Singh et al., 2016). In combination with different functional genomic approaches, the abovementioned omics approaches help to develop improved varieties with enhanced abiotic stress tolerance (Mosa et al., 2017). Several quantitative trait loci (QTLs) and candidate genes have been identified for zinc, iron, and Cd tolerance in various plant species which can be utilized for crop improvement by marker-assisted selection or QTL pyramiding (Courbot et al., 2007; Meyer et al., 2016; Zhang et al., 2017). Several previous studies have also reported improvement in heavy metal stress tolerance of plants by genetic engineering (Eapen and D'Souza, 2005; Farinati et al., 2010; Verma P.K. et al., 2016; Verma et al., 2017). Further, since plant breeding and genetic engineering is a labor intensive and time consuming process, there is a need to develop newer strategies or techniques that would be helpful for sustained crop production and productivity under heavy metal stress. Plantassociated microbes could be used as an alternate strategy for sustainable agricultural production. Numerous plant-associated microbes namely, bacteria and fungi are known to exhibit plant-growth promoting traits under heavy metal stress. These microbes impart favorable effects on plants via several direct and indirect mechanisms such as biofilm formation, siderophores, exopolysaccharide, and phytohormones production (Tiwari et al., 2016, 2017b). Since microbial heavy metal remediation does not involve any transgenic modifications, it is ethically and societally acceptable. Even though heavy metal tolerance in plants through microbial remediation has been investigated for many years, there is still considerable interest in extensive studies on plant-microbe-metal association due to their direct effects on enhanced biomass production and heavy metal tolerance (Glick, 2003; Taj and Rajkumar, 2016; Hansda and Kumar, 2017).
This review thus summarizes the recent advances in plantassociated microbes in metal remediation and stress tolerance in plants.

\section{PLANT GROWTH UNDER THE INFLUENCE OF HIGHLY TOXIC METALS}

Among numerous heavy metals, four heavy metals $\mathrm{As}, \mathrm{Pb}, \mathrm{Cd}$, and $\mathrm{Hg}$ are considered as the most toxic metals by the Agency for Toxic Substances and Disease Registry (ATSDR, 2003), based on their toxicity, frequency of occurrence, and most importantly, their exposure potential to flora and fauna. Origin and impact of these four heavy metals on environment and plant growth are briefly described below.

\section{Arsenic}

Arsenic is a naturally occurring metal which pose serious health hazards to millions of people across the globe (Kumar et al., 2015). It is usually originated via volcanic action, erosion of rocks, and by human activities such as applications of pesticides and wood preservatives, mining and smelting operations (Wang and Mulligan, 2006; Tripathi et al., 2007; Neumann et al., 2010). The contamination of As in groundwater used for irrigation and drinking is a worldwide problem as it not only affects crop productivity, but also accumulates in different plant tissues including grains and contaminates food chain (Verma P.K. et al., 2016). Recently, several studies have been carried out to investigate the physiological and molecular mechanisms of As toxicity, accumulation, detoxification, and tolerance in various plants including rice, lettuce, spinach, and carrot (Kumar et al., 2015). Inorganic arsenate $\mathrm{As}(\mathrm{V})$ and arsenite $\mathrm{As}(\mathrm{III})$ are two forms of As that exist in the environment. Both As(III) and $\mathrm{As}(\mathrm{V})$ are toxic and are regarded as major environmental pollutants based on United States Environmental Protection Agency (USEPA) evaluation (Tripathi et al., 2007; Verma et al., 2017). As(III) is more toxic than $\mathrm{As}(\mathrm{V})$ and act by interrupting biological functions in plants via different manner as, for example, it binds to proteins with sulfhydryl groups, interfering with their functions (Verma S. et al., 2016). It also generates ROS, inhibits respiration by binding to vicinal thiols in pyruvate dehydrogenase and 2-oxo-glutarate dehydrogenase, and act indirectly as a mutagen by inducing intrachromosomal homologous recombination (Helleday et al., 2000). On the other hand, in plants, $\mathrm{As}(\mathrm{V})$ interferes with oxidative phosphorylation and ATP synthesis during energy metabolism (Carbonell et al., 1998; Verma S. et al., 2016).

\section{Lead}

Lead is one of the most widely and evenly distributed trace metals that exist in various forms in the natural sources. It can affect soil, flora, and fauna health by contaminations from leaded fuels, dust, old lead plumbing pipes, various industrial sites, or even old orchard sites in production where lead arsenate is used (Tangahu et al., 2011). $\mathrm{Pb}^{2+}$ is non-biodegradable and its long-term exposure is found to be acutely toxic to both plants and animals and has several harmful effects on biological 
systems including soil properties [e.g., pH, organic carbon, amorphous iron, and aluminum oxides (FEAL), and cation exchange capacity; Bradham et al., 2006; Pehlivan et al., 2009]. If proper remedial action not taken, high soil $\mathrm{Pb}$ levels may never return to normal (Traunfeld and Clement, 2001). Pb impairs various biological processes in plants including seed germination, seedling development, root elongation, transpiration, chlorophyll biosynthesis, and cell division (Pourrut et al., 2011; Kumar et al., 2017). It also changes cell membrane permeability by reacting with active groups of different metabolic enzymes, with the phosphate groups of ADP or ATP, and by replacing essential ions, thus causing phytotoxicity (Pourrut et al., 2011; Kumar et al., 2017). Pb toxicity leads to inhibition of ATP production, induces lipid peroxidation, and DNA damage by over production of ROS.

\section{Cadmium}

Cadmium is considered to be one of the most phytotoxic heavy metals. Since it is highly soluble in water, it is easily taken up by plants representing the main entry pathway into the food chain causing serious human health hazards (Buchet et al., 1990). Cd has been classified as a potent human carcinogen by The International Agency for Research on Cancer (IARC, 1993; Gianazza et al., 2007; Gill and Tuteja, 2011). Interestingly, it has reported that it is commonly released into the arable soil from industrial processes and farming practices (Wagner, 1993) and also that crops are the main source of Cd intake by humans (Satarug et al., 2002; Gill and Tuteja, 2011). Even at low concentrations $\mathrm{Cd}$ can severely alter several enzyme activities including those involved in the Calvin cycle, carbohydrate and phosphorus metabolism, and $\mathrm{CO}_{2}$ fixation (Sandalio et al., 2001; Verma and Dubey, 2001; Sharma and Dubey, 2006; Gill and Tuteja, 2011) ultimately resulting in stunted growth, chlorosis, leaf epinasty, alterations in chloroplast ultrastructure, inhibition of photosynthesis and pollen germination and tube growth, induction of lipid peroxidation, and alterations in nitrogen (N) and sulfur (S) metabolism and disruption of antioxidant machinery (Gill and Tuteja, 2011).

\section{Mercury}

Mercury is a natural component of the Earth's crust that accumulates in land and water ecosystems, mainly as a consequence of different anthropological actions such as mining and industrial activities (Järup, 2003; Montero-Palmero et al., 2014). The large input of $\mathrm{Hg}$ into the arable lands has resulted in the widespread occurrence of $\mathrm{Hg}$-contamination in the entire food chain. In the environment several forms of $\mathrm{Hg}$ exist such as elemental $\left(\mathrm{Hg}^{0}\right)$, inorganic $\left(\mathrm{Hg}^{2+}\right)$, associated with ions $(\mathrm{HgS}$, $\left.\mathrm{ClHg}_{2}, \mathrm{Hg}_{2} \mathrm{Cl}_{2}\right)$, and organic $\left(\mathrm{CH}_{3}-\mathrm{Hg}\right)$ but in agricultural soils the ionic form is predominant $\left(\mathrm{Hg}^{2+}\right.$ ) (Zhou et al., 2008; Azevedo and Rodriguez, 2012). Increasing evidence has shown that $\mathrm{Hg}^{2+}$ can readily accumulate in higher plants (Israr et al., 2006; Yadav, 2010). At lower concentrations $\mathrm{Hg}^{2+}$ may not significantly affect plant growth but at higher concentrations it becomes highly phytotoxic to plant cells and can cause visible injuries and physiological disorders (Ortega-Villasante et al., 2005; Zhou et al., 2007). Binding of $\mathrm{Hg}^{2+}$ to water channel proteins leads to leaf stomata closure and physical impediment of water flow in plants (Zhang and Tyerman, 1999; Zhou et al., 2008). Additionally, it has also been reported to interfere with mitochondrial activity (Zhou et al., 2008). Mercuric ions are further reported to induce oxidative stress by stimulating generation of ROS in plants leading to disruption of biomembrane lipids and cellular metabolism, as well as increased activities of antioxidant enzymes like SOD, POD, or APX indicating the degree of stress (Cargnelutti et al., 2006; Zhou et al., 2007).

\section{HEAVY METAL SIGNALING AND TOLERANCE IN PLANTS}

In the last few decades, the research areas pertaining to plant responses and tolerance to heavy metal stress have rapidly progressed. Several genes that are induced under metal stress have been identified through various omics approaches as, for example, transcriptome analysis in different plants including Arabidopsis, Brassica, and Lycopersicum revealed role of several transcription factors (TFs) such as $b H L H, b Z I P, A P 2 / E R F$, and $D R E B$ under heavy metal stress (LeDuc et al., 2006; Shameer et al., 2009; Singh et al., 2016). Use of various proteomics techniques such as 2-D electrophoresis, MALDI-TOF, LC-MS have led to the discovery target proteins that take part in heavy metal detoxification in several plants including Oryza sativa, Zea mays, Arabidopsis, and Populus sp. (Lingua et al., 2012; Wang et al., 2013; Singh et al., 2016). Similarly, various amino acids, amines, organic acids, phenol, glutathione, and $\alpha$-tocopherol are some metabolites which have been reported to be involved under heavy metal stress tolerance (Collin et al., 2008; Yusuf et al., 2012; Singh et al., 2016). However, the functions of several of them are still not known owing to the complexity in plant responses to these stresses. Heavy metal stress signal transduction is initiated by receptors/ion channels by perception of stress signal(s) and further by non-protein messengers such as cyclic nucleotides, calcium, and hydrogen ions (Figure 1). Several kinases and phosphatases relay the stress signals that further leads to gene expression of various TFs and synthesis of metal-detoxifying peptides (Rao et al., 2011; Islam et al., 2015; Kumar and Trivedi, 2016). Heavy metal(s) activates distinct signaling pathways in plants such as calcium-dependent signaling, mitogen-activated protein kinase signaling, ROS signaling, and hormone signaling that enhance the expression of TFs and/or stress-responsive genes (Dubey et al., 2014; Kumar and Trivedi, 2016). Diverse $\mathrm{Ca}^{2+}$ sensors such as calmodulins (CaMs), CaM-like proteins, calcineurin B-like proteins (CBLs), and $\mathrm{Ca}^{2+}$-dependent protein kinases (CDPKs) exist in plants that sense, decode, and convey the alterations in cytosolic $\mathrm{Ca}^{2+}$ concentration for the stress response (Conde et al., 2011; Steinhorst and Kudla, 2014). Transcript profiling of rice roots exposed to long-term and short-term $\mathrm{Cr}$ stress suggested the involvement of CDPKs as their activity increased with increasing $\mathrm{Cr}(\mathrm{VI})$ concentration (Huang et al., 2014). In foxtail millet, $\mathrm{Ca}^{2+}$ activates antioxidant enzymes and provides tolerance against $\mathrm{Cr}$ stress (Fang et al., 2014). Similarly, MAPKs signaling cascade phosphorylate numerous TFs such as ABRE, 


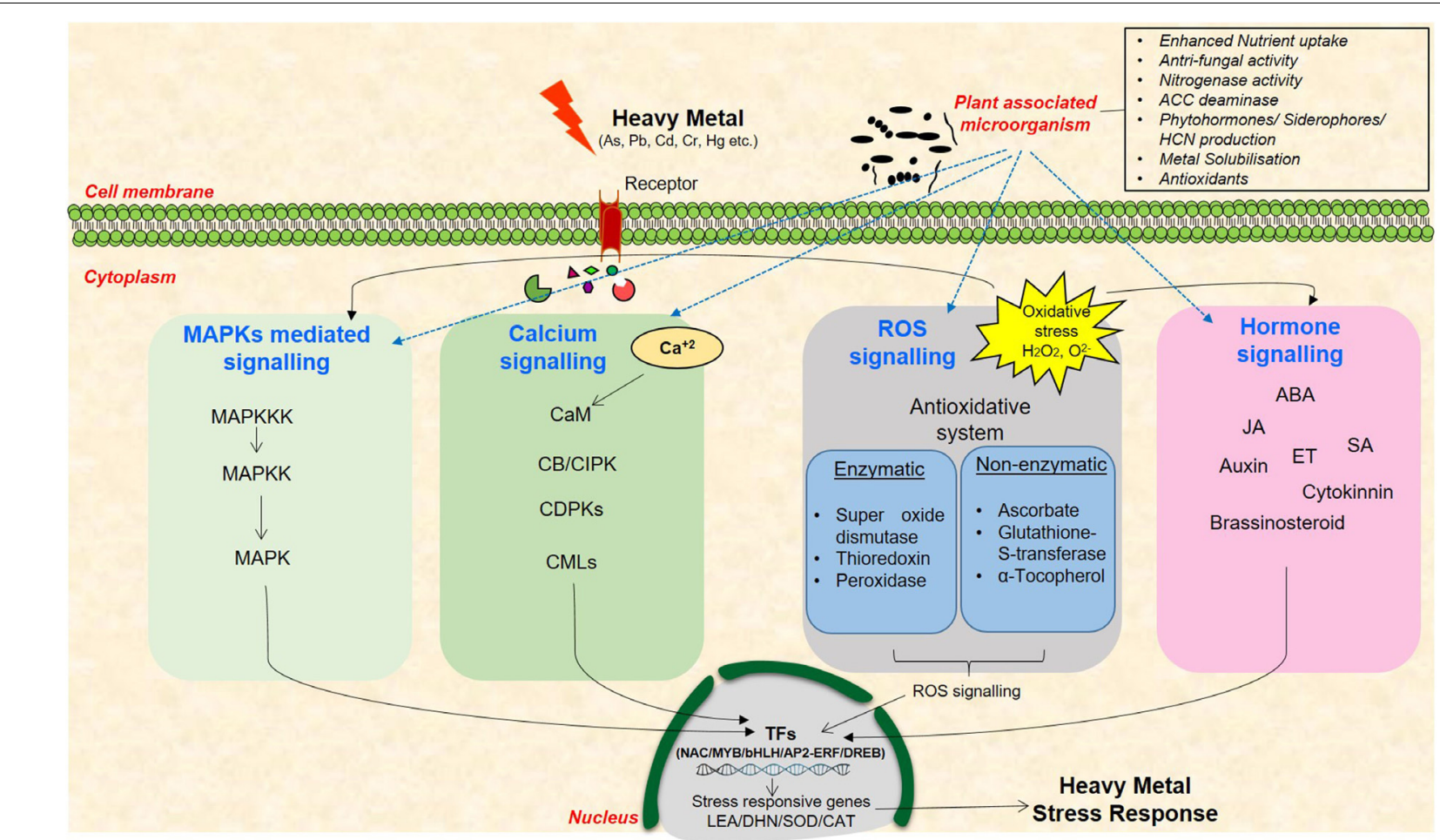

FIGURE 1 | A schematic representation of heavy metal stress signaling cascade in plants and the existing cross-talk among the networks of plant-microbe-metal interaction. These signaling pathways include MAPKs, calcium, ROS, and hormone signaling molecules that mediate signal transduction to enhance the expression of stress-responsive genes.

DREB, bZIP, MYB, MYC, NAC, and WRKY thus influencing metal stress response (Lin and Aarts, 2012; Tiwari et al., 2017a). High levels of $\mathrm{Cu}$ and $\mathrm{Cd}$ are known to activate distinct MAPKs in Medicago sativa (Jonak et al., 2004). Similarly, Cd induces OsMAPK2 and myelin basic protein $(M B P)$ kinase gene in rice (Yeh et al., 2004). Several studies have also suggested heavy metalmediated MAPKs activation via ROS generation, accumulation, and alteration in antioxidant system in Arabidopsis and rice (Liu et al., 2010; Kumar and Trivedi, 2016). ROS are also known to disrupt various phytohormone signaling pathways including auxin, ethylene, and JA. A recent study demonstrated that JA exposure improved antioxidant response leading to $\mathrm{Cd}$ stress tolerance in rice (Singh and Shah, 2014). Comparative transcriptome analysis of As(III)-treated rice seedlings suggested modulation of signal transduction, plant defense, and hormonal signaling processes such as ABA metabolism (Chakrabarty et al., 2009). The above observations clearly suggest that variation in the levels of phytohormones change plant response to metal stress.

Several reports also indicate the role of signaling molecules in providing plant-associated-beneficial microbes-mediated abiotic stress tolerance in plants as, for example, MAPK5 was found to be differentially expressed in rice roots treated with Bacillus amyloliquefaciens, a plant growth promoting rhizobacteria (PGPR) under salt stress indicating the induction of MAPKs signaling in presence of PGPR in plants (Nautiyal et al., 2013). Altered expression of At3g57530 responsible for calcium- and CaM-dependent protein kinase activity was reported in Arabidopsis under Pseudomonas putida and Pseudomonas fluorescens treatment (Wang et al., 2005; Srivastava et al., 2012). The expression of several downstream stress-responsive TFs such as MYB, NAC, and bZIP were also found to be modulated by PGPR treatment in several plants including rice, chickpea, and Arabidopsis (Srivastava et al., 2012; Tiwari et al., 2016, 2017b). Role of phytohormones ABA, SA, JA, and ethylene have also been elucidated in PGPR inoculated plants under stressed conditions (Tiwari et al., 2016, 2017b). The induction of these genes which are central to heavy metal stress signaling, in the presence of plant-associated microbes as well indicate the complex cross-talk between plant, microbes, and heavy metals in stress response and tolerance. Therefore, an understanding of the intricate metal stress signaling pathways and the existing crosstalk among the networks of plant-microbe-metal interaction is extremely important to elucidate the stress-responsive networks in plants.

\section{MICROBIAL REMEDIATION OF HEAVY METALS FOR PLANT GROWTH PROMOTION}

Remediation of heavy metals is necessary for the protection and conservation of the environment (Glick, 2010). For the elimination of heavy metals from the environment, numerous 
physicochemical and biological techniques have been adopted. Physicochemical techniques are rapid but are regarded as challenging due to the cost involved and technical complexity. They also cause adverse effects on soil physical, chemical, and biological properties, and lead to secondary pollution (Glick, 2010; Sheoran et al., 2011; Ali et al., 2013; Ullah et al., 2015). On the other hand, biological remediation is considered as the most effective method of toxic metal removal as these are natural, environment friendly, low cost, and high societal acceptance technologies (Doble and Kumar, 2005). One such technology is the use of plant growth promoting microbes for bioremediation of heavy metal polluted soil and is quite important in the context of global climate change and excessive fertilizer use in agricultural soils (Nautiyal et al., 2013; Tiwari et al., 2016). Microbes are known for enhancement of plant growth and survival under heavy metal stress condition as they have the capability of consuming waste and converting the complex waste into simple non-toxic by products/compounds. This is feasible because microorganisms have developed many resistance mechanisms for survival in the presence of toxic heavy metals in their environment (Thassitou and Arvanitoyannis, 2001; Mustapha and Halimoon, 2015). Microbes also enhance bioavailability of metals from soil by chelation, acidification, and precipitation as, for example, organic acids released by microbes and plant roots lower the soil $\mathrm{pH}$ and helps in sequestration of metal ions (Mishra et al., 2017). Microbial remediation processes via plant-associated microbes involved in heavy metal removal is represented in Figure 2. These resistance mechanisms developed by microbes include metal sorption, bioaccumulation, and enzymatic oxidation or reduction to a non-toxic form, and efflux of heavy metals from the cell (François et al., 2012; Monteiro et al., 2012; Hrynkiewicz and Baum, 2014; Mustapha and Halimoon, 2015). Here we have provided a list of recently studied plant-associated microbes that respond to various metal stress in plants (Table 1).

\section{Remediation of Heavy Metals by Bacteria}

Bacteria are the most crucial microbial organisms used for the remediation of heavy metal contaminated soils (Chen et al., 2015). Bacteria alleviate heavy metal ion toxicity by immobilizing, mobilizing, uptake, and transformation of heavy metals (Hassan et al., 2017). Moreover, numerous free-living as well as symbiotic PGPR resides in the soil environment around plant root that can positively alter plant growth and its productivity by the production of growth regulators via supplying and facilitating nutrient uptake from soil (Nadeem et al., 2014). Several studies have been reported where PGPR act as potential elicitors for abiotic stress tolerance including heavy metal tolerance (Dary et al., 2010; Tiwari et al., 2016, 2017b). They limit bioavailability of metals by forming complexes with siderophores, particular metabolites, and bacterial transporters (Rajkumar et al., 2010; Ahemad, 2012). These microorganisms of agronomic importance have evolved various mechanisms to avoid heavy metal stress including: (a) transport of metals across cytoplasmic membrane; (b) biosorption and bioaccumulation to the cell walls; (c) metal entrapment in the

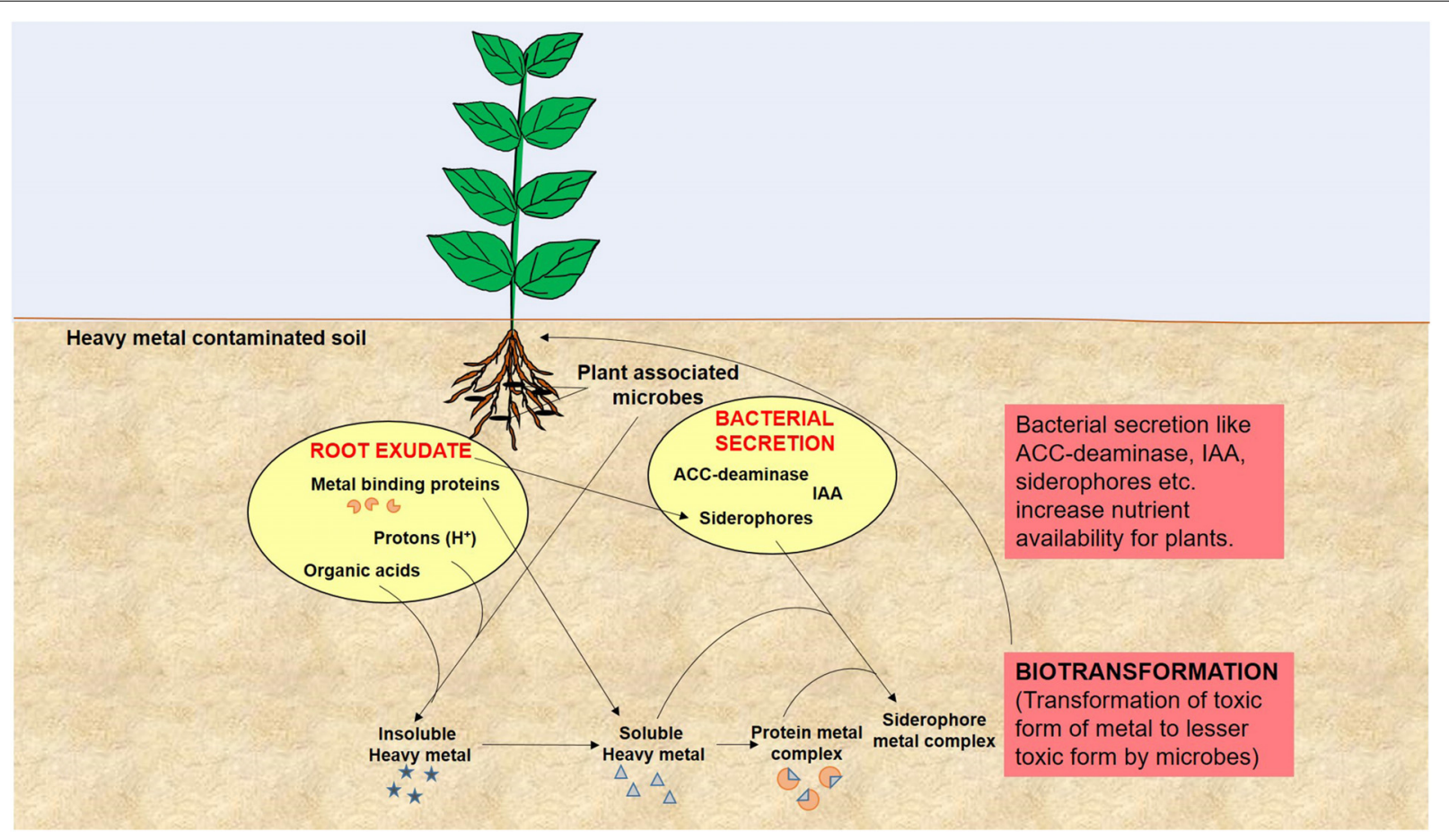

FIGURE 2 | A model of microbial remediation processes involved in heavy metal removal elaborates modulation of plant growth and alteration of soil physicochemical properties by root exudates and bacterial secretion to enhance metal bioavailability and biotransformation that leads to rapid detoxification and/or removal of heavy metal from soil. 
TABLE 1 | List of plant-associated microbes reported for plant growth promotion under heavy metal stress (2010 onward).

\begin{tabular}{|c|c|c|c|c|}
\hline S. No. & Microorganisms & Heavy metals & Plants & Reference \\
\hline 1. & Bacillus cereus, Pseudomonas moraviensis & $\mathrm{Cu}, \mathrm{Cr}, \mathrm{Co}, \mathrm{Cd}, \mathrm{Ni}, \mathrm{Mn}, \mathrm{Pb}$ & Triticum aestivum & Hassan et al., 2017 \\
\hline 2. & $\begin{array}{l}\text { Microbacterium sp. CE3R2, } \\
\text { Curtobacterium sp. NM1R1 }\end{array}$ & $\mathrm{Zn}, \mathrm{Pb}, \mathrm{Cu}, \mathrm{As}$ & Brassica nigra & Román-Ponce et al., 2017 \\
\hline 3. & $\begin{array}{l}\text { Bacteroidetes bacterium, Pseudomonas } \\
\text { fluorescens }\end{array}$ & $\mathrm{Cd}, \mathrm{Cu}, \mathrm{Pb}, \mathrm{Zn}$ & Brassica napus & Dąbrowska et al., 2017 \\
\hline 4. & Kocuria sp. CRB15 & $\mathrm{Cu}$ & Brassica nigra & Hansda and Kumar, 2017 \\
\hline 5. & Klebsiella pneumoniae & $\mathrm{Cd}$ & Oryza sativa & Pramanik et al., 2017 \\
\hline 6. & $\begin{array}{l}\text { Enterobacter ludwigii, Klebsiella } \\
\text { pneumoniae }\end{array}$ & $\mathrm{Hg}$ & Triticum aestivum & Gontia-Mishra et al., 2016 \\
\hline 7. & Azospirillum & $\mathrm{Pb}, \mathrm{Cd}$ & Panicum virgatum & Arora et al., 2016 \\
\hline 8. & Enterobacter, Leifsonia, Klebsiella, Bacillus & $\mathrm{Cd}$ & Zea mays & Ahmad et al., 2016 \\
\hline 9. & Pseudomonas putida & $\mathrm{Cd}$ & Eruca sativa & Kamran et al., 2015 \\
\hline 10. & $\begin{array}{l}\text { Rhodococcus erythropolis, Achromobacter } \\
\text { sp., Microbacterium sp. }\end{array}$ & $\mathrm{Zn}, \mathrm{Cd}$ & Trifolium repens & Pereira et al., 2015 \\
\hline 11. & $\begin{array}{l}\text { Variovorax paradoxus, Rhodococcus sp., } \\
\text { Flavobacterium sp. }\end{array}$ & $\mathrm{Cd}$ & Brassica juncea & Belimov et al., 2015 \\
\hline 12. & Bacillus pumilus E2S2, Bacillus sp. E1S2 & $\mathrm{Cd}, \mathrm{Zn}$ & Sedum plumbizincicola & Ma et al., 2015 \\
\hline 13. & Rhizobium leguminosarum & $\mathrm{Zn}$ & Brassica juncea & Adediran et al., 2015 \\
\hline 14. & Glomus versiforme & $\mathrm{Cd}$ & Solanum nigrum & Liu et al., 2015 \\
\hline 15. & Rhizophagus clarus & $\mathrm{Pb}$ & Cymbopogon citratus & Lermen et al., 2015 \\
\hline 16. & Pseudomonas sp. LK9 & $\mathrm{Cd}, \mathrm{Zn}, \mathrm{Cu}$ & Solanum nigrum & Chen et al., 2014 \\
\hline 17. & Bacillus licheniformis & $\mathrm{Ni}$ & Oryza sativa & Jamil et al., 2014 \\
\hline 18. & Rahnella sp. JN6 & $\mathrm{Cd}, \mathrm{Pb}, \mathrm{Zn}$ & Brassica napus & He et al., 2013 \\
\hline 19. & Bacillus thuringiensis GDB-1 & As, $\mathrm{Cu}$ & Alnus firma & Babu et al., 2013 \\
\hline 20. & $\begin{array}{l}\text { Ralstonia eutropha, Chryseobacterium } \\
\text { humi }\end{array}$ & Zn, Cd & Helianthus annuus & Marques et al., 2013 \\
\hline 21. & Staphylococcus arlettae & As & Brassica juncea & Srivastava et al., 2013 \\
\hline 22. & Ochrobactrum sp., Bacillus sp. & $\mathrm{Cd}, \mathrm{Pb}, \mathrm{As}$ & Oryza sativa & Pandey et al., 2013 \\
\hline 23. & $\begin{array}{l}\text { Paenibacillus macerans, Bacillus } \\
\text { endophyticus, Bacillus pumilus }\end{array}$ & $\mathrm{Cu}, \mathrm{Ni}, \mathrm{Zn}$ & Brassica juncea & Tiwari et al., 2012 \\
\hline 24. & Bacillus sp. MN3-4 & $\mathrm{Pb}$ & Alnus firma & Shin et al., 2012 \\
\hline 25. & Psychrobacter sp. SRS8 & $\mathrm{Ni}$ & $\begin{array}{l}\text { Helianthus annuus, Ricinus } \\
\text { communis }\end{array}$ & Ma et al., 2011 \\
\hline 26. & Bacillus sp. SLS18 & $\mathrm{Cd}$ & Solanum nigrum & Luo et al., 2011 \\
\hline 27. & Glomus mosseae & $\mathrm{Cd}, \mathrm{Pb}$ & Cajanus cajan & Garg and Aggarwal, 2011 \\
\hline 28. & Bacillus cereus, Candida parapsilosis & Fe, Mn, Zn, Cd & Trifolium repens & Azcón et al., 2010 \\
\hline 29. & Paecilomyces lilacinus $\mathrm{NH} 1$ & $\mathrm{Cd}$ & Solanum nigrum & Gao et al., 2010 \\
\hline 30. & $\begin{array}{l}\text { Bradyrhizobium sp. } 750 \text {, Pseudomonas } \\
\text { sp., Ochrobactrum cytisi }\end{array}$ & $\mathrm{Cu}, \mathrm{Cd}, \mathrm{Pb}$ & Lupinus luteus & Dary et al., 2010 \\
\hline
\end{tabular}

extracellular capsules; (d) heavy metals precipitation; and (e) metal detoxification via oxidation-reduction (Zubair et al., 2016). Heavy-metal-tolerant PGPR including Bacillus, Pseudomonas, Streptomyces, and Methylobacterium have the potential to improve growth and production of crops by reducing the detrimental effects of heavy metals (Sessitsch et al., 2013). Previous study reported Cd resistant Ochrobactrum sp. and $\mathrm{Pb}$ and As resistant Bacillus spp. have several PGPR traits that help in bioremediation and growth promotion of a rice cultivar (Pandey et al., 2013). Different rhizobacteria also have been reported that take part in metal accumulation and helps hyperaccumulating plants in uptake of heavy metals and their tolerance (Thijs et al., 2017). Further, it has been reported that use of microbes with some additives for the plants grown in heavy metal polluted soil are more beneficial than without additives (Mishra et al., 2017). A recent study showed that addition of thiosulfate with metal-tolerant microbes enhanced mobilization and uptake of As and $\mathrm{Hg}$ in Brassica juncea and Lupinus albus promoting bioavailability and phytoextraction (Franchi et al., 2017). These methods can aid both the biocontrol and bioremediation process simultaneously in polluted soils.

In spite of these practices, nowadays, the use of genetically transformed bacteria in heavy metal bioremediation is gaining great consideration; however, this limited to laboratory trials only (Gupta and Singh, 2017). Symbiotic relationship between plants and genetically transformed bacteria helps in in situ bioremediation of organic pollutants (Ullah et al., 2015; Ashraf et al., 2017). However, only a few evidences are available that highlights the remediation of heavy metals through such 
TABLE 2 | List of genetically modified plant-associated microbes for heavy metal stress tolerance (based on Ullah et al., 2015).

\begin{tabular}{|c|c|c|c|c|c|}
\hline S. No. & Genetically engineered microbe & Modified gene expression & Associated plant & Heavy metal(s) & Reference \\
\hline 1. & Pseudomonas putida & Phytochelatin synthase & Triticum aestivum & $\mathrm{Cd}, \mathrm{Hg}, \mathrm{Ag}$ & Yong et al., 2014 \\
\hline 2. & Mesorhizobium huakuii & Metallothionein, phytochelatin synthase & Astragalus sinicus & $\mathrm{Cd}, \mathrm{Cu}, \mathrm{Zn}, \mathrm{As}$ & Ike et al., 2008 \\
\hline 3. & Mesorhizobium huakuii & Metallothionein, phytochelatin synthase & Astragalus sinicus & $\mathrm{Cd}$ & Ike et al., 2007 \\
\hline 4. & Pseudomonas putida & Expression of metal binding peptide & Helianthus annuus & $\mathrm{Cd}$ & Wu et al., 2006 \\
\hline 5. & Mesorhizobium huakuii & Phytochelatin synthase & Astragalus sinicus & $\mathrm{Cd}$ & Sriprang et al., 2003 \\
\hline 6. & Meshorhizobium huakuii & Metallothionein & Astragalus sinicus & $\mathrm{Cd}$ & Sriprang et al., 2002 \\
\hline 7. & Enterobacter cloacae & EC 4.1.99.4 & Brassica napus & As & Nie et al., 2002 \\
\hline 8. & Ralstonia eutropha & Metallothionein & Nicotiana benthamiana & $\mathrm{Cd}$ & Valls et al., 2000 \\
\hline
\end{tabular}

symbiotic associations (Ullah et al., 2015). Examples of few genetically engineered PGPR are listed in Table 2. Recently elimination of toxic metals through a novel phytobacterial strategy, i.e., via use of genetically transformed PGPR has been suggested (Ullah et al., 2015). Genetically transformed bacteria possess one or more genes to increase remediation of heavy metals. In this context, genes for metal chelators, metal homeostasis, transporters, biodegradative enzymes, metal uptake regulators, and biotic and abiotic stress tolerance are important candidates for making recombinant bacteria (Singh et al., 2011).

\section{Remediation of Heavy Metals by Fungi}

Numerous filamentous fungi belonging to the genera Trichoderma, Penicillium, Aspergillus, and Mucor have been described as having the ability to tolerate heavy metal stress (Ezzouhri et al., 2009; Oladipo et al., 2017). Fungal cell walls have excellent metal binding properties due to presence of negative charge on the different functional groups, e.g., carboxylic, amine or sulfhydryl, phosphate, in different wall components (Tobin, 2001; Ong et al., 2017). A study showed interaction of Aspergillus niger var. tubingensis Ed8 with $\mathrm{Cr}(\mathrm{VI})$ mainly in a reduction process and also in a sorption process (Coreño-Alonso et al., 2014). Previous studies reported reduction in As induced stress in chickpea through Trichoderma sp. (Tripathi et al., 2013; Tripathi et al., 2017).

Arbuscular mycorrhizal fungi (AMF) are also one of the most prominent soil microorganisms. They establish direct physical link between soil and plant roots which increase root surface area facilitating nutrient absorption by the plants (Saxena et al., 2017). AM fungi are also involved in alleviating metal toxicity to the host plant (Leyval et al., 1997; Meharg, 2003). The specific role of arbuscular mycorrhizae in the host plant on exposure to heavy metal depends on a variety of factors, including the plant species and ecotype, the fungal species and ecotype, the metal and its availability; soil edaphic conditions, including soil fertility; and plant growth conditions, such as light intensity or root density (Pawlowska and Charvat, 2004). Similar to PGPR, several mechanisms have been hypothesized for toxic metal direction and allocation in plant roots in the presence of AMF including (a) heavy metals bound to cell wall and deposit in the vacuoles of AMF, (b) metal sequestration by the help of siderophores in the soil or into root apoplasm, (c) metals bound to metallothioneins or phytochelatins inside the fungal or plant cells, and (d) metal transporters at the tonoplast of both plants and fungi catalyze the transport of metals from cytoplasm (Jan and Parray, 2016).

\section{CONCLUSION AND FUTURE PERSPECTIVES}

Heavy metal contamination and remediation has received considerable attention in today's world owing to the fact that several heavy metals cannot be degraded and hence persist in the soil. Several strategies have been successfully applied to generate plants which are able to grow in metal contaminated soils and accumulate or tolerate metal stress. Use of microbial approach for heavy metal tolerance and remediation is an eco-friendly and economic approach. Since the plant heavy metal uptake and tolerance depend on various factors, interactions between plant and microbes can play an important role in successful survival and growth of plants in contaminated soils. Plant growth promoting microbes also assist plant growth by changing bioavailability of heavy metal. These beneficial effects exhibited by microbes, together with the suggested interrelationship between heavy metal tolerance and plant growth promoting ability, indicates that their exploitation in remediating metal contaminated soils might have significant potential in near future. In spite of these practices, genetically engineered microbes also have been used for remediation processes. Undoubtedly these engineered microbes have greater remediation potential but their impact on ecosystems needs to be elucidated before commercialization. Despite several findings to date, various steps of regulatory networks via plant-associated microbes in heavy metal stress are still unknown, and more investigations need to be done for unraveling the cross-talk among soilmicrobe and metal interaction in different crops. Additionally, synergistic action of plant and microbe and their mechanism for metal mobilization, transformation, and detoxification should also be studied. Further monitoring and managing microbial heavy metal remediation requires the characterization of the fate and behavior of the compounds of interest in the environment. However, at present, it is difficult to understand the environmental impacts of various metals mostly as a consequence of insufficient information being available about them. Thus this 
highlights the importance of a consistent link between research and development for the assessment and treatment of emerging metal pollutants and the tools, equipment and knowhow that contributes toward the fulfillment of these challenges.

\section{AUTHOR CONTRIBUTIONS}

ST and CL wrote and reviewed the manuscript.

\section{REFERENCES}

Adediran, G. A., Ngwenya, B. T., Mosselmans, J. F. W., Heal, K. V., and Harvie, B. A. (2015). Mechanism behind bacteria induced plant growth promotion and $\mathrm{Zn}$ accumulation in Brassica juncea. J. Hazard. Mater. 283, 490-499. doi: 10.1016/j.jhazmat.2014.09.064

Ahemad, M. (2012). Implication of bacterial resistance against heavy metals in bioremediation: a review. J. Inst. Integr. Omics Appl. Biotechnol. 3, 39-46.

Ahmad, I., Akhtar, M. J., Asghar, H. N., Ghafoor, U., and Shahid, M. (2016). Differential effects of plant growth-promoting Rhizobacteria on maize growth and cadmium uptake. J. Plant Growth Regul. 35, 303-315. doi: 10.1007/s00344015-9534-5

Ali, H., Khan, E., and Sajad, M. A. (2013). Phytoremediation of heavy metals-Concepts and applications. Chemosphere 91, 869-881. doi: 10.1016/j. chemosphere.2013.01.075

Amari, T., Ghnaya, T., and Abdelly, C. (2017). Nickel, cadmium and lead phytotoxicity and potential of halophytic plants in heavy metal extraction. S. Afr. J. Bot. 111, 99-110. doi: 10.1016/j.sajb.2017.03.011

Arora, K., Sharma, S., and Monti, A. (2016). Bio-remediation of $\mathrm{Pb}$ and Cd polluted soils by switch grass: a case study in India. Int. J. Phytoremediation 18, 704-709. doi: 10.1080/15226514.2015.1131232

Ashraf, M. A., Hussain, I., Rasheed, R., Iqbal, M., Riaz, M., and Arif, M. S. (2017). Advances in microbe-assisted reclamation of heavy metal contaminated soils over the last decade: a review. J. Environ. Manage. 198, 132-143. doi: 10.1016/j. jenvman.2017.04.060

ATSDR (2003). Agency for Toxic Substances and Disease Registry. Available at: http://www.atsdr.cdc.gov/

Azcón, R., Perálvarez, M. D. C., Roldán, A., and Barea, J. M. (2010). Arbuscular mycorrhizal fungi, Bacillus cereus, and Candida parapsilosis from a multicontaminated soil alleviate metal toxicity in plants. Microb. Ecol. 59, 668-677. doi: 10.1007/s00248-009-9618-5

Azevedo, R., and Rodriguez, E. (2012). Phytotoxicity of mercury in plants: a review. J. Bot. 2012:848614. doi: 10.1155/2012/848614

Babu, A. G., Kim, J. D., and Oh, B. T. (2013). Enhancement of heavy metal phytoremediation by Alnus firma with endophytic Bacillus thuringiensis GDB1. J. Hazard. Mater. 250, 477-483. doi: 10.1016/j.jhazmat.2013.02.014

Belimov, A. A., Puhalsky, I. V., Safronova, V. I., Shaposhnikov, A. I., Vishnyakova, M. A., Semenova, E. V., et al. (2015). Role of plant genotype and soil conditions in symbiotic plant-microbe interactions for adaptation of plants to cadmiumpolluted soils. Water Air Soil Pollut. 226:264. doi: 10.1007/s11270-0152537-9

Bradham, K. D., Dayton, E. A., Basta, N. T., Schroder, J., Payton, M., and Lanno, R. P. (2006). Effect of soil properties on lead bioavailability and toxicity to earthworms. Environ. Toxicol. Chem. 25, 769-775. doi: 10.1897/04-552R.1

Buchet, J. P., Lauwerys, R., Roels, H., Bernard, A., Bruaux, P., Claeys, F., et al. (1990). Renal effects of cadmium body burden of the general population. Lancet 336, 699-702. doi: 10.1016/0140-6736(90)92201-R

Carbonell, A. A., Aarabi, M. A., Delaune, R. D., Grambrell, R. P., and Patrick, W. H. (1998). Arsenic in wetland vegetation: availability, phytotoxicity, uptake and effects on plants growth and nutrition. Sci. Total Environ. 217, 189-199. doi: 10.1016/S0048-9697(98)00195-8

Cargnelutti, D., Tabaldi, L. A., Spanevello, R. M., de Oliveira Jucoski, G., Battisti, V., Redin, M., et al. (2006). Mercury toxicity induces oxidative stress in growing cucumber seedlings. Chemosphere 65, 999-1006. doi: 10.1016/j.chemosphere. 2006.03.037

\section{FUNDING}

This study was supported by the In-house Project "Microbial intervention for amelioration of abiotic and biotic stresses in plants" (OLP0105) from the Council of Scientific and Industrial Research (CSIR), New Delhi, India. CL acknowledges "StartUp Research Grant for INSA Young Scientist" (Grant No. INSA/SP/YSP/148/2017/1582) by the Indian National Science Academy (INSA), New Delhi.

Chakrabarty, D., Trivedi, P. K., Misra, P., Tiwari, M., Shri, M., Shukla, D., et al. (2009). Comparative transcriptome analysis of arsenate and arsenite stresses in rice seedlings. Chemosphere 74, 688-702. doi: 10.1016/j.chemosphere.2008. 09.082

Chen, L., Luo, S., Li, X., Wan, Y., Chen, J., and Liu, C. (2014). Interaction of Cd hyperaccumulator Solanum nigrum L. and functional endophyte Pseudomonas sp. Lk9 on soil heavy metals uptake. Soil Biol. Biochem. 68, 300-308. doi: 10.1016/j.soilbio.2013.10.021

Chen, M., Xu, P., Zeng, G., Yang, C., Huang, D., and Zhang, J. (2015). Bioremediation of soils contaminated with polycyclic aromatic hydrocarbons, petroleum, pesticides, chlorophenols and heavy metals by composting: applications, microbes and future research needs. Biotechnol. Adv. 33, 745-755. doi: 10.1016/j.biotechadv.2015.05.003

Collin, V. C., Eymery, F., Genty, B., Rey, P., and Havaux, M. (2008). Vitamin E is essential for the tolerance of Arabidopsis thaliana to metal-induced oxidative stress. Plant Cell Environ. 31, 244-257.

Conde, A., Chaves, M. M., and Geros, H. (2011). Membrane transport, sensing and signaling in plant adaptation to environmental stress. Plant Cell Physiol. 52, 1583-1602. doi: 10.1093/pcp/pcr107

Coreño-Alonso, A., Solé, A., Diestra, E., Esteve, I., Gutiérrez-Corona, J. F., López, G. R., et al. (2014). Mechanisms of interaction of chromium with Aspergillus niger var. tubingensis strain Ed8. Bioresour. Technol. 158, 188-192. doi: 10.1016/ j.biortech.2014.02.036

Courbot, M., Willems, G., Motte, P., Arvidsson, S., Roosens, N., SaumitouLaprade, P., et al. (2007). A major quantitative trait locus for cadmium tolerance in Arabidopsis halleri colocalizes with HMA4, a gene encoding a heavy metal ATPase. Plant Physiol. 144, 1052-1065. doi: 10.1104/pp.106.095133

Dąbrowska, G., Hrynkiewicz, K., Trejgell, A., and Baum, C. (2017). The effect of plant growth-promoting rhizobacteria on the phytoextraction of $\mathrm{Cd}$ and $\mathrm{Zn}$ by Brassica napus L. Int. J. Phytoremediation 19, 597-604. doi: 10.1080/15226514. 2016.1244157

Dary, M., Chamber-Pérez, M. A., Palomares, A. J., and Pajuelo, E. (2010). "In situ" phytostabilisation of heavy metal polluted soils using Lupinus luteus inoculated with metal resistant plant-growth promoting rhizobacteria. J. Hazard. Mater. 177, 323-330. doi: 10.1016/j.jhazmat.2009.12.035

Doble, M., and Kumar, A. (2005). Biotreatment of Industrial Effluents. Oxford: Butterworth-Heinemann, 19-38. doi: 10.1016/B978-075067838-4/50004-X

Dubey, S., Shri, M., Misra, P., Lakhwani, D., Bag, S. K., Asif, M. H., et al. (2014). Heavy metals induce oxidative stress and genome-wide modulation in transcriptome of rice root. Funct. Integr. Genomics 14, 401-417. doi: 10.1007/ s10142-014-0361-8

Eapen, S., and D'Souza, S. F. (2005). Prospects of genetic engineering of plants for phytoremediation of toxic metals. Biotechnol. Adv. 23, 97-114. doi: 10.1016/j. biotechadv.2004.10.001

Ezzouhri, L., Castro, E., Moya, M., Espinola, F., and Lairini, K. (2009). Heavy metal tolerance of filamentous fungi isolated from polluted sites in Tangier, Morocco. Afr. J. Microbiol. Res. 3, 35-48.

Fang, H., Jing, T., Liu, Z., Zhang, L., Jin, Z., and Pei, Y. (2014). Hydrogen sulfide interacts with calcium signaling to enhance the chromium tolerance in Setaria italica. Cell Calcium 56, 472-481. doi: 10.1016/j.ceca.2014.10.004

Farinati, S., Dalcorso, G., Varotto, S., and Furini, A. (2010). The Brassica juncea BjCdR15, an ortholog of Arabidopsis TGA3, is a regulator of cadmium uptake, transport and accumulation in shoots and confers cadmium tolerance in transgenic plants. New Phytol. 185, 964-978. doi: 10.1111/j.1469-8137.2009. 03132.x 
Franchi, E., Rolli, E., Marasco, R., Agazzi, G., Borin, S., Cosmina, P., et al. (2017). Phytoremediation of a multi contaminated soil: mercury and arsenic phytoextraction assisted by mobilizing agent and plant growth promoting bacteria. J. Soils Sediments 17, 1224-1236. doi: 10.1007/s11368-015-1346-5

François, F., Lombard, C., Guigner, J. M., Soreau, P., Brian-Jaisson, F., Martino, G., et al. (2012). Isolation and characterization of environmental bacteria capable of extracellular biosorption of mercury. Appl. Environ. Microbiol. 78, 1097-1106. doi: 10.1128/AEM.06522-11

Gao, Y., Miao, C., Mao, L., Zhou, P., Jin, Z., and Shi, W. (2010). Improvement of phytoextraction and antioxidative defense in Solanum nigrum L. under cadmium stress by application of cadmium-resistant strain and citric acid. J. Hazard. Mater. 181, 771-777. doi: 10.1016/j.jhazmat.2010.05.080

Garg, N., and Aggarwal, N. (2011). Effects of interactions between cadmium and lead on growth, nitrogen fixation, phytochelatin, and glutathione production in mycorrhizal Cajanus cajan (L.) Millsp. J. Plant Growth Regul. 30, 286-300. doi: 10.1007/s00344-010-9191-7

Gianazza, E., Wait, R., Sozzi, A., Regondi, S., Saco, D., Labra, M., et al. (2007). Growth and protein profile changes in Lepidium sativum L. plantlets exposed to cadmium. Environ. Exp. Bot. 59, 179-187. doi: 10.1016/j.envexpbot.2005. 12.005

Gill, S. S., and Tuteja, N. (2010). Reactive oxygen species and antioxidant machinery in abiotic stress tolerance in crop plants. Plant Physiol. Biochem. 48, 909-930. doi: 10.1016/j.plaphy.2010.08.016

Gill, S. S., and Tuteja, N. (2011). Cadmium stress tolerance in crop plants: probing the role of sulfur. Plant Signal. Behav. 6, 215-222. doi: 10.4161/psb.6.2.14880

Glick, B. R. (2003). Phytoremediation: synergistic use of plants and bacteria to clean up the environment. Biotechnol. Adv. 21,383-393. doi: 10.1016/S0734-9750(03) 00055-7

Glick, B. R. (2010). Using soil bacteria to facilitate phytoremediation. Biotechnol. Adv. 28, 367-374. doi: 10.1016/j.biotechadv.2010.02.001

Gontia-Mishra, I., Sapre, S., Sharma, A., and Tiwari, S. (2016). Alleviation of mercury toxicity in wheat by the interaction of mercury-tolerant plant growthpromoting rhizobacteria. J. Plant Growth Regul. 35, 1000-1012. doi: 10.1007/ s00344-016-9598-x

Gupta, S., and Singh, D. (2017). "Role of genetically modified microorganisms in heavy metal bioremediation," in Advances in Environmental Biotechnology, eds R. Kumar, A. Sharma, and S. Ahluwalia (Singapore: Springer), 197-214.

Hansda, A., and Kumar, V. (2017). Cu-resistant Kocuria sp. CRB15: a potential PGPR isolated from the dry tailing of Rakha copper mine. 3 Biotech. 7:132. doi: 10.1007/s13205-017-0757-y

Hassan, T. U., Bano, A., and Naz, I. (2017). Alleviation of heavy metals toxicity by the application of plant growth promoting rhizobacteria and effects on wheat grown in saline sodic field. Int. J. Phytoremediation 19, 522-529. doi: 10.1080/15226514.2016.1267696

He, H., Ye, Z., Yang, D., Yan, J., Xiao, L., Zhong, T., et al. (2013). Characterization of endophytic Rahnella sp. JN6 from Polygonum pubescens and its potential in promoting growth and $\mathrm{Cd}, \mathrm{Pb}, \mathrm{Zn}$ uptake by Brassica napus. Chemosphere 90, 1960-1965. doi: 10.1016/j.chemosphere.2012.10.057

Helleday, T., Nilsson, R., and Jenssen, D. (2000). Arsenic (III) and heavy metal ions induce intrachromosomal homologous recombination in the hprt gene of V79 Chinese hamster cells. Environ. Mol. Mutagen. 35, 114-122. doi: 10.1002/(SICI) 1098-2280(2000)35:2<114::AID-EM6>3.0.CO;2-Q

Hrynkiewicz, K., and Baum, C. (2014). "Application of microorganisms in bioremediation of environment from heavy metals," in Environmental Deterioration and Human Health, eds A. Malik, E. Grohmann, and R. Akhtar (Dordrecht: Springer), 215-227.

Huang, T. L., Huang, L. Y., Fu, S. F., Trinh, N. N., and Huang, H. J. (2014). Genomic profiling of rice roots with short-and long-term chromium stress. Plant Mol. Biol. 86, 157-170. doi: 10.1007/s11103-014-0219-4

IARC (1993). IARC Monographs on the Evaluation of Carcinogenic Risk to Humans. Beryllium, Cadmium, Mercury and Exposures in the Glass Manufacturing Industry, Vol. 58. Lyon: International Agency for Research on Cancer Publication, 41-117.

Ibrahim, M. A., Khan, P. R., Hegazy, S. S., Hashim, E. A., Azamal, H., Ansari, M. K. A., et al. (2015). Improving the phytoextraction capacity of plants to scavenge heavy-metal infested sites. Environ. Rev. 23, 1-22.

Ike, A., Sriprang, R., Ono, H., Murooka, Y., and Yamashita, M. (2007). Bioremediation of cadmium contaminated soil using symbiosis between leguminous plant and recombinant rhizobia with the MTL4 and the PCS genes. Chemosphere 66, 1670-1676. doi: 10.1016/j.chemosphere.2006.07.058

Ike, A., Sriprang, R., Ono, H., Murooka, Y., and Yamashita, M. (2008). Promotion of metal accumulation in nodule of Astragalus sinicus by the expression of the iron-regulated transporter gene in Mesorhizobium huakuii subsp. rengei B3. J. Biosci. Bioeng. 105, 642-648. doi: 10.1263/jbb.105.642

Islam, E., Khan, M. T., and Irem, S. (2015). Biochemical mechanisms of signalling: perspectives in plant under arsenic stress. Ecotoxicol. Environ. Saf. 114, 126-133. doi: 10.1016/j.ecoenv.2015.01.017

Israr, M., Sahi, S., Datta, R., and Sarkar, D. (2006). Bioaccumulation and physiological effects of mercury in Sesbania drummondii. Chemosphere 65, 591-598. doi: 10.1016/j.chemosphere.2006.02.016

Jamil, M., Zeb, S., Anees, M., Roohi, A., Ahmed, I., ur Rehman, S., et al. (2014). Role of Bacillus licheniformis in phytoremediation of nickel contaminated soil cultivated with rice. Int. J. Phytoremediation 16, 554-571. doi: 10.1080/ 15226514.2013.798621

Jan, S., and Parray, J. A. (eds). (2016). "Use of mycorrhiza as metal tolerance strategy in plants," in Approaches to Heavy Metal Tolerance in Plants (Singapore: Springer), 57-68. doi: 10.1007/978-981-10-1693-6_4

Järup, L. (2003). Hazards of heavy metal contamination. Br. Med. Bull. 68, 167-182. doi: $10.1093 / \mathrm{bmb} / \mathrm{ldg} 032$

Jonak, C., Nakagami, H., and Hirt, H. (2004). Heavy metal stress. Activation of distinct mitogen-activated protein kinase pathways by copper and cadmium. Plant Physiol. 136, 3276-3283. doi: 10.1104/pp.104.045724

Kamran, M. A., Syed, J. H., Eqani, S. A., Munis, M. F. H., and Chaudhary, H. J. (2015). Effect of plant growth-promoting rhizobacteria inoculation on cadmium (Cd) uptake by Eruca sativa. Environ. Sci. Pollut. Res. Int. 22, 9275-9283. doi: 10.1007/s11356-015-4074-x

Kumar, B., Smita, K., and Flores, L. C. (2017). Plant mediated detoxification of mercury and lead. Arabian J. Chem. 10, S2335-S2342. doi: 10.1093/pcp/pcu117

Kumar, S., Dubey, R. S., Tripathi, R. D., Chakrabarty, D., and Trivedi, P. K. (2015). Omics and biotechnology of arsenic stress and detoxification in plants: current updates and prospective. Environ. Int. 74, 221-230. doi: 10.1016/j.envint.2014. 10.019

Kumar, S., and Trivedi, P. K. (2016). "Heavy metal stress signaling in plants," in Plant Metal Interaction- Emerging Remediation Techniques, ed. P. Ahmad (Amsterdan: Elsevier), 585-603. doi: 10.1016/B978-0-12-803158-2.00025-4

LeDuc, D. L., Abdel Samie, M., Móntes-Bayon, M., Wu, C. P., Reisinger, S. J., and Terry, N. (2006). Overexpressing both ATP sulfurylase and selenocysteine methyltransferase enhances selenium phytoremediation traits in Indian mustard. Environ. Pollut. 144, 70-76. doi: 10.1016/j.envpol.2006. 01.008

Lermen, C., Morelli, F., Gazim, Z. C., Silva, P. A. D., Goncalves, J. E., Dragunski, D. C., et al. (2015). Essential oil content and chemical composition of Cymbopogon citratus inoculated with arbuscular mycorrhizal fungi under different levels of lead. Ind. Crops Prod. 76, 734-738. doi: 10.1016/j.indcrop. 2015.07.009

Leyval, C., Turnau, K., and Haselwandter, K. (1997). Effect of heavy metal pollution on mycorrhizal colonization and function-physiological, ecological and applied aspects. Mycorrhiza 7, 139-153. doi: 10.1007/s005720050174

Lin, Y. F., and Aarts, M. G. (2012). The molecular mechanism of zinc and cadmium stress response in plants. Cell. Mol. Life Sci. 69, 3187-3206. doi: 10.1007/s00018012-1089-z

Lingua, G., Bona, E., Todeschini, V., Cattaneo, C., Marsano, F., Berta, G., et al. (2012). Effects of heavy metals and arbuscular mycorrhiza on the leaf proteome of a selected poplar clone: a time course analysis. PLoS One 7:e38662. doi: 10.1371/journal.pone.0038662

Liu, H., Yuan, M., Tan, S. Y., Yang, X. P., Lan, Z., Jiang, Q. Y., et al. (2015). Enhancement of arbuscular mycorrhizal fungus (Glomus versiforme) on the growth and Cd uptake by Cd-hyperaccumulator Solanum nigrum. Appl. Soil Ecol. 89, 44-49. doi: 10.1016/j.apsoil.2015.01.006

Liu, X. M., Kim, K. E., Kim, K. C., Nguyen, X. C., Han, H. J., Jung, M. S., et al. (2010). Cadmium activates Arabidopsis MPK3 and MPK6 via accumulation of reactive oxygen species. Phytochemistry 71, 614-618. doi: 10.1016/j.phytochem. 2010.01.005

Luo, S. L., Chen, L., Chen, J. I., Xiao, X., Xu, T. Y., Wan, Y., et al. (2011). Analysis and characterization of cultivable heavy metal-resistant bacterial endophytes isolated from Cd hyperaccumulator Solanum nigrum L. and their 
potential use for phytoremediation. Chemosphere 85, 1130-1138. doi: 10.1016/ j.chemosphere.2011.07.053

Ma, Y., Oliviera, R. S., Nai, F., Rajkumar, M., Luo, Y., Rocha, I., et al. (2015). The hyperaccumulator Sedum plumbizincicola harbors metal-resistant endophytic bacteria that improve its phytoextraction capacity in multi-metal contaminated soil. J. Environ. Manage. 156, 62-69. doi: 10.1016/j.jenvman.2015. 03.024

Ma, Y., Prasad, M. N. V., Rajkumar, M., and Freitas, H. (2011). Plant growth promoting rhizobacteria and endophytes accelerate phytoremediation of metalliferous soils. Biotechnol. Adv. 29, 248-258. doi: 10.1016/j.biotechadv. 2010.12.001

Marques, A. P., Moreira, H., Franco, A. R., Rangel, A. O., and Castro, P. M. (2013). Inoculating Helianthus annuus (sunflower) grown in zinc and cadmium contaminated soils with plant growth promoting bacteriaEffects on phytoremediation strategies. Chemosphere 92, 74-83. doi: 10.1016/ j.chemosphere.2013.02.055

Meharg, A. A. (2003). The mechanistic basis of interactions between mycorrhizal associations and toxic metal cations. Mycol. Res. 107, 1253-1265. doi: 10.1017/ S0953756203008608

Meyer, C. L., Pauwels, M., Briset, L., Godé, C., Salis, P., Bourceaux, A., et al. (2016). Potential preadaptation to anthropogenic pollution: evidence from a common quantitative trait locus for zinc and cadmium tolerance in metallicolous and nonmetallicolous accessions of Arabidopsis halleri. New Phytol. 212, 934-943. doi: 10.1111/nph.14093

Mishra, J., Singh, R., and Arora, N. K. (2017). Alleviation of heavy metal stress in plants and remediation of soil by rhizosphere microorganisms. Front. Microbiol. 8:1706. doi: 10.3389/fmicb.2017.01706

Monteiro, C. M., Castro, P. M., and Malcata, F. X. (2012). Metal uptake by microalgae: underlying mechanisms and practical applications. Biotechnol. Prog. 28, 299-311. doi: 10.1002/btpr.1504

Montero-Palmero, M. B., Ortega-Villasante, C., Escobar, C., and Hernández, L. E. (2014). Are plant endogenous factors like ethylene modulators of the early oxidative stress induced by mercury? Front. Environ. Sci. 2:34. doi: 10.3389/ fenvs.2014.00034

Mosa, K. A., Ismail, A., and Helmy, M. (2017). "Functional genomics combined with other omics approaches for better understanding abiotic stress tolerance in plants," in Plant Stress Tolerance, ed. Sunkar and Ramanjulu (Cham: Springer International Publishing), 55-73.

Mustapha, M. U., and Halimoon, N. (2015). Screening and isolation of heavy metal tolerant bacteria in industrial effluent. Procedia Environ. Sci. 30, 33-37. doi: $10.1016 /$ j.proenv.2015.10.006

Nabulo, G., Black, C. R., and Young, S. D. (2011). Trace metal uptake by tropical vegetables grown on soil amended with urban sewage sludge. Environ. Pollut. 159, 368-376. doi: 10.1016/j.envpol.2010.11.007

Nadeem, S. M., Ahmad, M., Zahir, Z. A., Javaid, A., and Ashraf, M. (2014). The role of mycorrhizae and plant growth promoting rhizobacteria (PGPR) in improving crop productivity under stressful environments. Biotechnol. Adv. 32, 429-448. doi: 10.1016/j.biotechadv.2013.12.005

Nautiyal, C. S., Srivastava, S., Chauhan, P. S., Seem, K., Mishra, A., and Sopory, S. K. (2013). Plant growth-promoting bacteria Bacillus amyloliquefaciens NBRISN13 modulates gene expression profile of leaf and rhizosphere community in rice during salt stress. Plant Physiol. Biochem. 66, 1-9. doi: 10.1016/j.plaphy.2013. 01.020

Neumann, R. B., Ashfaque, K. N., Badruzzaman, A. B. M., Ali, M. A., Shoemaker, J. K., and Harvey, C. F. (2010). Anthropogenic influences on groundwater arsenic concentrations in Bangladesh. Nat. Geosci. 3, 46-52. doi: 10.1038/ ngeo685

Nie, L., Shah, S., Rashid, A., Burd, G. I., Dixon, D. G., and Glick, B. R. (2002). Phytoremediation of arsenate contaminated soil by transgenic canola and the plant growth-promoting bacterium Enterobacter cloacae CAL2. Plant Physiol. Biochem. 40, 355-361. doi: 10.1016/S0981-9428(02)01375-X

Oladipo, O. G., Awotoye, O. O., Olayinka, A., Bezuidenhout, C. C., and Maboeta, M. S. (2017). Heavy metal tolerance traits of filamentous fungi isolated from gold and gemstone mining sites. Braz. J. Microbiol. 49, 29-37. doi: 10.1016/j. bjm.2017.06.003

Ong, G. H., Ho, X. H., Shamkeeva, S., Fernando, M. S., Shimen, A., and Wong, L. S. (2017). Biosorption study of potential fungi for copper remediation from Peninsular Malaysia. Remediat. J. 27, 59-63. doi: 10.1002/rem.21531
Ortega-Villasante, C., Rellán-Álvarez, R., Del Campo, F. F., Carpena-Ruiz, R. O., and Hernández, L. E. (2005). Cellular damage induced by cadmium and mercury in Medicago sativa. J. Exp. Bot. 56, 2239-2251. doi: 10.1093/jxb/eri223

Pandey, S., Ghosh, P. K., Ghosh, S., De, T. K., and Maiti, T. K. (2013). Role of heavy metal resistant Ochrobactrum sp. and Bacillus spp. strains in bioremediation of a rice cultivar and their PGPR like activities. J. Microbiol. 51, 11-17. doi: 10.1007/s12275-013-2330-7

Panuccio, M. R., Sorgona, A., Rizzo, M., and Cacco, G. (2009). Cadmium adsorption on vermiculite, zeolite and pumice: batch experiment studies. J. Environ. Manage. 90, 364-374. doi: 10.1016/j.jenvman.2007.10.005

Pawlowska, T. E., and Charvat, I. (2004). Heavy-metal stress and developmental patterns of arbuscular mycorrhizal fungi. Appl. Environ. Microbiol. 70, 6643-6649. doi: 10.1128/AEM.70.11.6643-6649.2004

Pehlivan, E., Özkan, A. M., Dinc, S., and Parlayici, S. (2009). Adsorption of Cu2+ and $\mathrm{Pb} 2+$ ion on dolomite powder. J. Hazard. Mater. 167, 1044-1049. doi: 10.1016/j.jhazmat.2009.01.096

Pereira, S. I. A., Barbosa, L., and Castro, P. M. L. (2015). Rhizobacteria isolated from a metal polluted area enhance plant growth in zinc and cadmiumcontaminated soil. Int. J. Environ. Sci. Technol. 12, 2127-2142. doi: 10.1007/ s13762-014-0614-z

Pierart, A., Shahid, M., Séjalon-Delmas, N., and Dumat, C. (2015). Antimony bioavailability: knowledge and research perspectives for sustainable agricultures. J. Hazard. Mater. 289, 219-234. doi: 10.1016/j.jhazmat.2015.02.011

Pourrut, B., Jean, S., Silvestre, J., and Pinelli, E. (2011). Lead-induced DNA damage in Vicia faba root cells: potential involvement of oxidative stress. Mutat. Res. 726, 123-128. doi: 10.1016/j.mrgentox.2011.09.001

Pramanik, K., Mitra, S., Sarkar, A., Soren, T., and Maiti, T. K. (2017). Characterization of cadmium-resistant Klebsiella pneumoniae MCC 3091 promoted rice seedling growth by alleviating phytotoxicity of cadmium. Environ. Sci. Pollut. Res. 24, 24419-24437. doi: 10.1007/s11356-017-0033-z

Rajkumar, M., Ae, N., Prasad, M. N. V., and Freitas, H. (2010). Potential of siderophore-producing bacteria for improving heavy metal phytoextraction. Trends Biotechnol. 28, 142-149. doi: 10.1016/j.tibtech.2009.12.002

Rao, K. P., Vani, G., Kumar, K., Wankhede, D. P., Misra, M., Gupta, M., et al. (2011). Arsenic stress activates MAP kinase in rice roots and leaves. Arch. Biochem. Biophys. 506, 73-82. doi: 10.1016/j.abb.2010.11.006

Román-Ponce, B., Reza-vázquez, D. M., Gutiérrez-paredes, S., María de jesús, D. E., Maldonado-hernández, J., Bahena-osorio, Y., et al. (2017). Plant growth-promoting traits in rhizobacteria of heavy metal-resistant plants and their effects on Brassica nigra seed germination. Pedosphere 27, 511-526. doi: 10.1016/S1002-0160(17)60347-3

Salla, V., Hardaway, C. J., and Sneddon, J. (2011). Preliminary investigation of Spartina alterniflora for phytoextraction of selected heavy metals in soils from Southwest Louisiana. Microchem. J. 97, 207-212. doi: 10.1016/j.microc.2010. 09.005

Sandalio, L. M., Dalurzo, H. C., Gomez, M., Romero-Puertas, M. C., and del Rio, L. A. (2001). Cadmium-induced changes in the growth and oxidative metabolism of pea plant. J. Exp. Bot. 52, 2115-2126. doi: 10.1093/jexbot/52.364. 2115

Satarug, S., Baker, J. R., Reilly, P. E. B., Moore, M. R., and Williams, D. J. (2002). Cadmium levels in the lung, liver, kidney cortex and urine samples from Australians without occupational exposure to metals. Arch. Environ. Health 57, 69-77. doi: 10.1080/00039890209602919

Saxena, B., Shukla, K., and Giri, B. (2017). "Arbuscular mycorrhizal fungi and tolerance of salt stress in plants," in Arbuscular Mycorrhizas and Stress Tolerance of Plants, ed. Q. S. Wu (Singapore: Springer), 67-97. doi: 10.1007/978-981-104115-0_4

Sessitsch, A., Kuffner, M., Kidd, P., Vangronsveld, J., Wenzel, W. W., Fallmann, K., et al. (2013). The role of plant-associated bacteria in the mobilization and phytoextraction of trace elements in contaminated soils. Soil Biol. Biochem. 60, 182-194. doi: 10.1016/j.soilbio.2013.01.012

Shahid, M., Khalid, S., Abbas, G., Shahid, N., Nadeem, M., Sabir, M., et al. (2015). "Heavy metal stress and crop productivity," in Crop Production and Global Environmental Issues, ed. K. R. Hakeem (Cham: Springer International Publishing), 1-25.

Shameer, K., Ambika, S., Varghese, S. M., Karaba, N., Udayakumar, M., and Sowdhamini, R. (2009). STIFDB-Arabidopsis stress responsive transcription factor dataBase. Int. J. Plant Genomics 2009:83429. doi: 10.1155/2009/583429 
Sharma, P., and Dubey, R. S. (2006). "Cadmium uptake and its toxicity in higher plants," in Cadmium Toxicity and Tolerance in Plants, eds N. A. Khan and Samiullah (New Delhi: Narosa Publishing House), 64-86.

Sheoran, V., Sheoran, A., and Poonia, P. (2011). Role of hyperaccumulators in phytoextraction of metals from contaminated mining sites: a review. Crit. Rev. Environ. Sci. Technol. 41, 168-214. doi: 10.1080/10643380902718418

Shin, M., Shim, J., You, Y., Myung, H., Bang, K. S., Cho, M., et al. (2012). Characterization of lead resistant endophytic Bacillus sp. MN3-4 and its potential for promoting lead accumulation in metal hyperaccumulator Alnus firma. J. Hazard. Mater. 19, 314-320. doi: 10.1016/j.jhazmat.2011.11.010

Singh, I., and Shah, K. (2014). Exogenous application of methyl jasmonate lowers the effect of cadmium-induced oxidative injury in rice seedlings. Phytochemistry 108, 57-66. doi: 10.1016/j.phytochem.2014.09.007

Singh, J. S., Abhilash, P. C., Singh, H. B., Singh, R. P., and Singh, D. P. (2011). Genetically engineered bacteria: an emerging tool for environmental remediation and future research perspectives. Gene 480, 1-9. doi: 10.1016/j. gene.2011.03.001

Singh, S., Parihar, P., Singh, R., Singh, V. P., and Prasad, S. M. (2016). Heavy metal tolerance in plants: role of transcriptomics, proteomics, metabolomics, and ionomics. Front. Plant Sci. 6:1143. doi: 10.3389/fpls.2015.01143

Sriprang, R., Hayashi, M., Ono, H., Takagi, M., Hirata, K., and Murooka, Y. (2003). Enhanced accumulation of $\mathrm{Cd} 2+$ by a Mesorhizobium sp. transformed with a gene from Arabidopsis thaliana coding for phytochelatin synthase. Appl. Environ. Microbiol. 69, 1791-1796. doi: 10.1128/AEM.69.3.1791-1796.2003

Sriprang, R., Hayashi, M., Yamashita, M., Ono, H., Saeki, K., and Murooka, Y. (2002). A novel bioremediation system for heavy metals using the symbiosis between leguminous plant and genetically engineered rhizobia. J. Biotechnol. 99, 279-293. doi: 10.1016/S0168-1656(02)00219-5

Srivastava, S., Chaudhry, V., Mishra, A., Chauhan, P. S., Rehman, A., Yadav, A., et al. (2012). Gene expression profiling through microarray analysis in Arabidopsis thaliana colonized by Pseudomonas putida MTCC5279, a plant growth promoting rhizobacterium. Plant Signal. Behav. 7, 235-245. doi: $10.4161 /$ psb. 18957

Srivastava, S., Verma, P. C., Chaudhary, V., Singh, N., Abhilash, P. C., Kumar, K. V., et al. (2013). Inoculation of arsenic-resistant Staphylococcus arlettae on growth and arsenic uptake in Brassica juncea (L.) Czern. Var. R-46. J. Hazard. Mater. 262, 1039-1047. doi: 10.1016/j.jhazmat.2012.08.019

Steinhorst, L., and Kudla, J. (2014). Signaling in cells and organisms-calcium holds the line. Curr. Opin. Plant Biol. 22, 14-21. doi: 10.1016/j.pbi.2014.08.003

Taj, Z. Z., and Rajkumar, M. (2016). "Perspectives of plant growth-promoting actinomycetes in heavy metal phytoremediation," in Plant Growth Promoting Actinobacteria, eds Subramaniam, Gopalakrishnan, Arumugam, Sathya, and Rajendran (Singapore: Springer), 213-231.

Tangahu, B. V., Sheikh Abdullah, S. R., Basri, H., Idris, M., Anuar, N., and Mukhlisin, M. (2011). A Review on heavy metals ( $\mathrm{As}, \mathrm{Pb}$, and $\mathrm{Hg}$ ) uptake by plants through phytoremediation. Int. J. Chem. Eng. 2011:31. doi: 10.1155/2011/ 939161

Thassitou, P., and Arvanitoyannis, I. (2001). Bioremediation: a novel approach to food waste management. Trends Food Sci. Technol. 12, 185-196. doi: 10.1016/ S0924-2244(01)00081-4

Thijs, S., Langill, T., and Vangronsveld, J. (2017). Chapter two-the bacterial and fungal microbiota of hyperaccumulator plants: small organisms, large influence. Adv. Bot. Res. 83, 43-86. doi: 10.1016/bs.abr.2016.12.003

Tiwari, S., Lata, C., Chauhan, P. S., and Nautiyal, C. S. (2016). Pseudomonas putida attunes morphophysiological, biochemical and molecular responses in Cicer arietinum L. during drought stress and recovery. Plant Physiol. Biochem. 99, 108-117. doi: 10.1016/j.plaphy.2015.11.001

Tiwari, S., Lata, C., Singh Chauhan, P., Prasad, V., and Prasad, M. (2017a). A functional genomic perspective on drought signalling and its crosstalk with phytohormone-mediated signalling pathways in plants. Curr. Genomics 18, 469-482. doi: 10.2174/1389202918666170605083319

Tiwari, S., Prasad, V., Chauhan, P. S., and Lata, C. (2017b). Bacillus amyloliquefaciens confers tolerance to various abiotic stresses and modulates plant response to phytohormones through osmoprotection and gene expression regulation in rice. Front. Plant Sci. 8:1510. doi: 10.3389/fpls.2017.01510

Tiwari, S., Singh, S. N., and Garg, S. K. (2012). Stimulated phytoextraction of metals from fly ash by microbial interventions. Environ. Technol. 33, 2405-2413. doi: 10.1080/09593330.2012.670269
Tobin, J. M. (2001). Fungal metal biosorption. Br. Mycol. Soc. Symp. Ser. 23, 424-444. doi: 10.1017/CBO9780511541780.016

Traunfeld, J. H., and Clement, D. L. (2001). Lead in Garden Soils. Home and Garden, Maryland Cooperative Extention. College Park, MD: University of Maryland.

Tripathi, P., Singh, P. C., Mishra, A., Chaudhry, V., Mishra, S., Tripathi, R. D., et al. (2013). Trichoderma inoculation ameliorates arsenic induced phytotoxic changes in gene expression and stem anatomy of chickpea (Cicer arietinum). Ecotoxicol. Environ. Saf. 89, 8-14. doi: 10.1016/j.ecoenv.2012.10.017

Tripathi, P., Singh, P. C., Mishra, A., Srivastava, S., Chauhan, R., Awasthi, S., et al. (2017). Arsenic tolerant Trichoderma sp. reduces arsenic induced stress in chickpea (Cicer arietinum). Environ. Pollut. 223, 137-145. doi: 10.1016/j.envpol. 2016.12.073

Tripathi, R. D., Srivastava, S., Mishra, S., Singh, N., Tuli, R., Gupta, D. K., et al. (2007). Arsenic hazards: strategies for tolerance and remediation by plants. Trends Biotechnol. 25, 158-165. doi: 10.1016/j.tibtech.2007.02.003

Ullah, A., Heng, S., Munis, M. F. H., Fahad, S., and Yang, X. (2015). Phytoremediation of heavy metals assisted by plant growth promoting (PGP) bacteria: a review. Environ. Exp. Bot. 117, 28-40. doi: 10.1016/j.envexpbot.2015. 05.001

Uzu, G., Sauvain, J.-J., Baeza-Squiban, A., Riediker, M., Hohl, M. S. S., Val, S., et al. (2011). In vitro assessment of the pulmonary toxicity and gastric availability of lead rich particles from a lead recycling plant. Environ. Sci. Technol. 45, 7888-7895. doi: 10.1021/es200374c

Valls, M., Atrian, S., de Lorenzo, V., and Fernández, L. A. (2000). Engineering a mouse metallothionein on the cell surface of Ralstonia eutropha $\mathrm{CH} 34$ for immobilization of heavy metals in soil. Nat. Biotechnol. 18, 661-665. doi: 10. $1038 / 76516$

Verma, P. K., Verma, S., Pande, V., Mallick, S., Tripathi, R. D., Dhankher, O. P., et al. (2016). Overexpression of rice glutaredoxin OsGrx_C7 and OsGrx_C2. 1 reduces intracellular arsenic accumulation and increases tolerance in Arabidopsis thaliana. Front. Plant Sci. 7:740.

Verma, S., and Dubey, R. S. (2001). Effect of Cadmium on soluble sugars and enzymes of their metabolism in rice. Biol. Plant. 44, 117-123. doi: 10.1023/A: 1017938809311

Verma, S., Verma, P. K., Meher, A. K., Bansiwal, A. K., Tripathi, R. D., and Chakrabarty, D. (2017). A novel fungal arsenic methyltransferase, WaarsM reduces grain arsenic accumulation in the transgenic rice plant. J. Hazard. Mater. 344, 626-634. doi: 10.1016/j.jhazmat.2017.10.037

Verma, S., Verma, P. K., Meher, A. K., Dwivedi, S., Bansiwal, A. K., Pande, V., et al. (2016). A novel arsenic methyltransferase gene of Westerdykella aurantiaca isolated from arsenic contaminated soil: phylogenetic, physiological, and biochemical studies and its role in arsenic bioremediation. Metallomics 8, 344-353. doi: 10.1039/c5mt00277j

Wagner, G. J. (1993). Accumulation of cadmium in crop plants and its consequences to human health. Adv. Agron. 51, 173-212. doi: 10.1016/S00652113(08)60593-3

Wang, R., Gao, F., Guo, B. Q., Huang, J. C., Wang, L., and Zhou, Y. J. (2013). Shortterm chromium-stress-induced alterations in the maize leaf proteome. Int. J. Mol. Sci. 14, 11125-11144. doi: 10.3390/ijms140611125

Wang, S., and Mulligan, C. N. (2006). Occurrence of arsenic contamination in Canada: sources, behavior and distribution. Sci. Total Environ. 366, 701-721. doi: 10.1016/j.scitotenv.2005.09.005

Wang, Y., Ohara, Y., Nakayashiki, H., Tosa, Y., and Mayama, S. (2005). Microarray analysis of the gene expression profile induced by the endophytic plant growth-promoting rhizobacteria, Pseudomonas fluorescens FPT9601-T5 in Arabidopsis. Mol. Plant Microbe Interact. 18, 385-396. doi: 10.1094/MPMI-180385

Wu, C. H., Wood, T. K., Mulchandani, A., and Chen, W. (2006). Engineering plant-microbe symbiosis for rhizoremediation of heavy metals. Appl. Environ. Microbiol. 72, 1129-1134. doi: 10.1128/AEM.72.2.1129-1134.2006

Xiong, T., Leveque, T., Shahid, M., Foucault, Y., Mombo, S., and Dumat, C. (2014). Lead and cadmium phytoavailability and human bioaccessibility for vegetables exposed to soil or atmospheric pollution by process ultrafine particles. J. Environ. Qual. 43, 1593-1600. doi: 10.2134/jeq2013.11.0469

Yadav, S. K. (2010). Heavy metals toxicity in plants: an overview on the role of glutathione and phytochelatins in heavy metal stress tolerance of plants. S. Afr. J. Bot. 76, 167-179. doi: 10.1016/j.sajb.2009.10.007 
Yeh, C. M., Hsiao, L. J., and Huang, H. J. (2004). Cadmium activates a mitogenactivated protein kinase gene and MBP kinases in rice. Plant Cell Physiol. 45, 1306-1312. doi: 10.1093/pcp/pch135

Yong, X., Chen, Y., Liu, W., Xu, L., Zhou, J., Wang, S., et al. (2014). Enhanced cadmium resistance and accumulation in Pseudomonas putida KT2440 expressing the phytochelatin synthase gene of Schizosaccharomyces pombe. Lett. Appl. Microbiol. 58, 255-261. doi: 10.1111/lam.12185

Yusuf, M., Fariduddin, Q., and Ahmad, A. (2012). 24-Epibrassinolide modulates growth, nodulation, antioxidant system, and osmolyte in tolerant and sensitive varieties of Vigna radiata under different levels of nickel: a shotgun approach. Plant Physiol. Biochem. 57, 143-153. doi: 10.1016/j.plaphy.2012.05.004

Zhang, J., Xu, J., Pasuquin, J., Chen, K., Dingkuhn, M., Naveed, S. A., et al. (2017). QTL mapping and candidate gene analysis of ferrous iron and zinc toxicity tolerance at seedling stage in rice by genome-wide association study. BMC Genomics 18:828. doi: 10.1186/s12864-017-4221-5

Zhang, W. H., and Tyerman, S. D. (1999). Inhibition of water channels by $\mathrm{HgCl} 2$ in intact wheat root cells. Plant Physiol. 120, 849-858. doi: 10.1104/pp.120.3.849

Zhou, Z. S., Huang, S. Q., Guo, K., Mehta, S. K., Zhang, P. C., and Yang, Z. M. (2007). Metabolic adaptations to mercury-induced oxidative stress in roots of
Medicago sativa L. J. Inorg. Biochem. 101, 1-9. doi: 10.1016/j.jinorgbio.2006. 05.011

Zhou, Z. S., Wang, S. J., and Yang, Z. M. (2008). Biological detection and analysis of mercury toxicity to alfalfa (Medicago sativa) plants. Chemosphere 70, 1500-1509. doi: 10.1016/j.chemosphere.2007.08.028

Zubair, M., Shakir, M., Ali, Q., Rani, N., Fatima, N., Farooq, S., et al. (2016). Rhizobacteria and phytoremediation of heavy metals. Environ. Technol. Rev. 5, 112-119. doi: 10.1080/21622515.2016.1259358

Conflict of Interest Statement: The authors declare that the research was conducted in the absence of any commercial or financial relationships that could be construed as a potential conflict of interest.

Copyright (c) 2018 Tiwari and Lata. This is an open-access article distributed under the terms of the Creative Commons Attribution License (CC BY). The use, distribution or reproduction in other forums is permitted, provided the original author(s) and the copyright owner are credited and that the original publication in this journal is cited, in accordance with accepted academic practice. No use, distribution or reproduction is permitted which does not comply with these terms. 